\title{
Synovial mast cell responses during clinical improvement in early rheumatoid arthritis
}

\author{
Ian Gotis-Graham, Malcolm D Smith, Angela Parker, H Patrick McNeil
}

\begin{abstract}
Objectives-To determine the synovial mast cell response in early rheumatoid arthritis (RA) during clinical improvement, and to examine for relations with clinical and histological parameters of disease activity.

Methods-Twenty two synovial samples were obtained from six patients with RA using needle arthroscopy. The mean disease duration at baseline was eight months, and two to three further samples were obtained over a mean follow up period of 15 months during which treatment initiated clinical improvement occurred. Sections were immunostained to detect $\mathrm{MC}_{\mathrm{T}}$ and $\mathrm{MC}_{\mathrm{TC}}$ mast cells and correlations were sought between clinical and histological data.
\end{abstract}

Results-The overall mean synovial mast cell density was 40.3 cells $/ \mathrm{mm}^{2}$, with regional densities of 60.6 and 34.2 mast cells $/ \mathrm{mm}^{2}$ in the superficial and deeper synovial layers respectively. The $\mathrm{MC}_{\mathrm{T}}$ subset predominated, outnumbering $\mathrm{MC}_{\mathrm{TC}}$ by 3:1. There was a significant correlation between the histological inflammation index and the $\mathrm{MC}_{\mathrm{T}}$ density, $(r=0.4, \mathrm{p}<$ 0.05 ) but not the $M_{\mathrm{TC}}$ subset. The regional distribution and predominant subset of mast cells varied in individual patient's synovia over time, with a trend towards restriction of the mast cell response to the superficial synovium during clinical improvement.

Inflammation

Research Unit, Schools of Pathology and Medicine, University of New South Wales, Australia

I Gotis-Graham

H P McNeil

Department of Rheumatology, Prince of Wales Hospital, Sydney, Australia H P McNeil

Rheumatology Research Unit, Repatriation General Hospital, Daw Park, Adelaide, Australia M D Smith

A Parker

Correspondence to: Dr H P McNeil, School of Pathology, University of New South Wales, Sydney, Australia 2052.

Accepted for publication 15 July 1998 because it contains tryptase and chymase whereas the other, $\mathrm{MC}_{\mathrm{T}}$, contains tryptase but not chymase. There is some evidence to suggest that these subsets are functionally distinct. Mast cell subsets localise to different areas of normal tissue: $\mathrm{MC}_{\mathrm{TC}}$ are the predominant type found in skin and bowel submucosa, whereas $\mathrm{MC}_{\mathrm{T}}$ are the predominant type in the interalveolar septa of lung and in mucosa of bowel. Whereas both subsets produce tryptase enzymes, $\mathrm{MC}_{\mathrm{TC}}$ contain, in addition to chymase, carboxypeptidase $\mathrm{A},{ }^{8}$ and a chymase-like proteinase, cathepsin $\mathrm{G},{ }^{9}$ which is also present in neutrophils and monocytes. Bradding et $a l^{10}$ have shown that mast cell subsets in asthmatic lung have different cytokine profiles with the $\mathrm{MC}_{\mathrm{TC}}$ predominantly containing interleukin 4 (IL4) whereas $\mathrm{MC}_{\mathrm{T}}$ preferentially produce IL5 and IL6, as well as some IL4.

Human mast cells differ in their response to various secretagogues. For example, C5a or compound 48/80 activate skin $\mathrm{MC}_{\mathrm{TC}}$ mast cells, whereas lung $\mathrm{MC}_{\mathrm{T}}$ cells are not responsive to these stimuli. ${ }^{11}$ Substance $P$ and morphine activate skin $\mathrm{MC}_{\mathrm{TC}}$ cells but not heart mast cells $\left(>90 \% \mathrm{MC}_{\mathrm{TC}}\right)$ nor lung mast cells. Mast cells purified from predominantly osteoarthritic synovia (reported to be $>90 \%$ $\mathrm{MC}_{\mathrm{TC}}$ ) were unresponsive to $\mathrm{C} 5 \mathrm{a}$, but were activated by substance $\mathrm{P}^{12}$ Thus, there is heterogeneity with respect to activation stimuli within the $\mathrm{MC}_{\mathrm{TC}}$ subset. The distribution of mast cell subsets within tissues is changed in disease states. Patients with the acquired immunodeficiency syndrome and those with combined immunodeficiency diseases have a selective deficiency of $\mathrm{MC}_{\mathrm{T}}$ in the small bowel, ${ }^{13}$ whereas patients with inflammatory skin conditions ${ }^{14}$ or scleroderma have infiltration of $\mathrm{MC}_{\mathrm{T}}$ cells into the skin. ${ }^{15}$

We recently defined certain aspects of the mast cell response in RA of relatively long disease duration. ${ }^{4}$ The mast cell density in RA was increased compared with synovium from normal and osteoarthritic joints. In $\mathrm{RA}, \mathrm{MC}_{\mathrm{TC}}$ cells were associated with areas of cellular, dense fibrous connective tissue, and were present in highest density in patients who had more severe or rapidly progressive disease. The $\mathrm{MC}_{\mathrm{T}}$ subset was associated with areas of inflammatory cell infiltration, although a correlation with an assessment of the degree of synovitis was not found. There was variability in the response between patients: some samples exhibited exclusive expansion of $\mathrm{MC}_{\mathrm{T}}$ cells, others only $\mathrm{MC}_{\mathrm{TC}}$, whereas most showed expansion of both. This finding raised the question of whether the type of mast cell response is fixed in certain people, or whether it changes depending upon the inflammatory processes occurring in the synovium at different time points. 
The aims of this study were to examine the mast cell density and subset distribution in early RA where the articular cartilage is still intact; to determine whether the mast cell response changes in the same patient over time, in particular during clinical improvement; and to further characterise the significance of the $\mathrm{MC}_{\mathrm{T}}$ and $\mathrm{MC}_{\mathrm{TC}}$ subsets in relation to the local inflammatory process and the clinical state of the disease. We optimised the detection of the $\mathrm{MC}_{\mathrm{TC}}$ subset in formalin fixed tissue using avidin and confirm this as a valid technique that can be used on routinely fixed tissue. Analysis was performed on coded tissue sections with the patient identification, clinical details and order of biopsies revealed only after all histological analysis was performed. The early stage of disease and the availability of follow up synovial biopsies have given further insights into potential functional roles of the $\mathrm{MC}_{\mathrm{T}}$ and $\mathrm{MC}_{\mathrm{TC}}$ subsets in rheumatoid inflammation.

\section{Methods}

PATIENTS

All patients met the American College of Rheumatology criteria for RA. ${ }^{16}$ Biopsies of synovium from involved knee joints were performed on six patients within a mean of eight months after first onset of symptoms before treatment with disease modifying drugs. After the start of treatment, each patient had a further two or three biopsies performed over a mean follow up period of 15 months (range 9-24 months). A total of 22 synovial biopsy specimens were available for analysis. Synovial tissue was collected using a needle arthroscope ${ }^{17}{ }^{18}$ Biopsy specimens were taken from areas of clearly visible synovium, usually the medial parapatellar gutter or the suprapatellar pouch. Previous studies have shown little variability in either standard histological ${ }^{19}$ or immunohistochemical ${ }^{20}$ findings when multiple samples of synovia taken from different areas of a single joint were compared, validating analysis of a single sample. Furthermore, the histomorphometric system used in this study (see below), analysed a relatively large area of synovium in two regions defined by reference to the synovial surface, which compensated for regional variations in the distribution of mast cells, and ensured valid comparison of values between samples. Follow up biopsy specimens were taken as close as possible to the site of the previous biopsy. Skin specimens were taken from normal areas of excised lesions. Tonsils were taken from routine tonsillectomy. All specimens were fixed in $10 \%$ formalin overnight, then embedded in paraffin wax.

The clinical disease activity was assessed at the time of each biopsy by recording patient swollen joints. Blood was collected for C reactive protein (CRP) measurements $(\mathrm{mg} / \mathrm{l})$. The assessment of disability used the Health Assessment Questionnaire (HAQ), and pain and overall well being used visual analogue scales. Parameters of clinical disease activity were combined to form a clinical index, and a disease severity index was derived by considering the disability caused by the disease and how quickly this had occurred (HAQ/duration of disease) as previously described. ${ }^{4}$ Some results from this study were compared with mast cell densities previously reported in synovia taken at the time of arthroplasty or arthroscopy from patients with RA of long duration, $(n=16$; mean disease duration 18 years), and in synovia taken from normal joints $(n=15$; taken at postmortem examination within 12 hours of death). ${ }^{4}$

\section{MATERIALS}

Hydrogen peroxide (Ajax Chemicals, Sydney, Australia), mouse monoclonal antihuman tryptase (clone AA1) and polyclonal rabbit antiCD3 (Dako, Denmark), biotinylated goat antimouse IgG, biotinylated goat antirabbit IgG, peroxidase conjugated streptavidin, avidinbiotin complex conjugated to horseradish peroxidase (ABC-HRP) and goat serum (Vector, Burlingame, CA), proteinase $\mathrm{K}$ (Boehringer Manheim, Sydney, Australia), 3-amino-9ethylcarbazole (Sigma, St Louis, MO), and crystal mount (Biomeda, Foster City, CA) were obtained as indicated. Rabbit immunoglobulin fraction-normal (Dako) and mouse IgG1 negative control monoclonal antibody (Silenus, Melbourne, Australia) were used as negative controls for the various primary antibodies.

\section{IMMUNOHISTOCHEMISTRY}

Two $\mu \mathrm{m}$ sections of skin and tonsil and $4 \mu \mathrm{m}$ sections of RA synovium were cut. For each patient, at each time point, adjacent sections were stained for tryptase, with avidin, for CD3 and with haematoxylin and eosin. Sections were digested with proteinase $\mathrm{K}(10 \mu \mathrm{g} / \mathrm{ml})$ for 20 minutes at $37^{\circ} \mathrm{C}$ before immunostaining. Staining for tryptase was performed using the AA1 antibody $(1 \mu \mathrm{g} / \mathrm{ml})$, which is a sensitive and specific marker of mast cells in formalin fixed tissue in which it has been shown to accurately assess mast cell density in direct comparison to Carnoy's fixed tissue. ${ }^{21}$ The technique was similar to that used for CD3 as previously described. ${ }^{4}$ As the anti-chymase antibody we previously used does not reliably stain formalin fixed tissue, we detected chymase containing cells by their ability to bind avidin. ${ }^{22-24}$ ABC-HRP was applied for $30 \mathrm{~min}-$ utes at room temperature, in the absence of blocking serum, followed by a freshly prepared solution of 3-amino-9-ethyl carbazole (0.4 $\mathrm{mg} / \mathrm{ml}$ of $0.05 \mathrm{M}$ acetate buffer, $\mathrm{pH}$ 5) containing $0.01 \%$ hydrogen peroxide. Although it has been previously well established that avidin binds only to chymase containing mast cells, and that such binding accurately quantitates mast cell density independent of methods of fixation or embedding, ${ }^{22-24}$ we confirmed the selectivity of avidin for the $\mathrm{MC}_{\mathrm{TC}}$ subset by staining serial sections of skin and tonsil fixed in formalin with anti-tryptase and with ABCHRP. In skin, where more that $99 \%$ of all mast cells belong to the $\mathrm{MC}_{\mathrm{TC}}$ subset, ${ }^{7} \mathrm{ABC}-\mathrm{HRP}$ only stained tryptase positive cells (fig 1a and b). In tonsil, ABC-HRP localised to cells in the fibrous tissue septa that were identified on the adjacent section as being tryptase positive. This accords with the known distribution of $\mathrm{MC}_{\mathrm{TC}}$ 

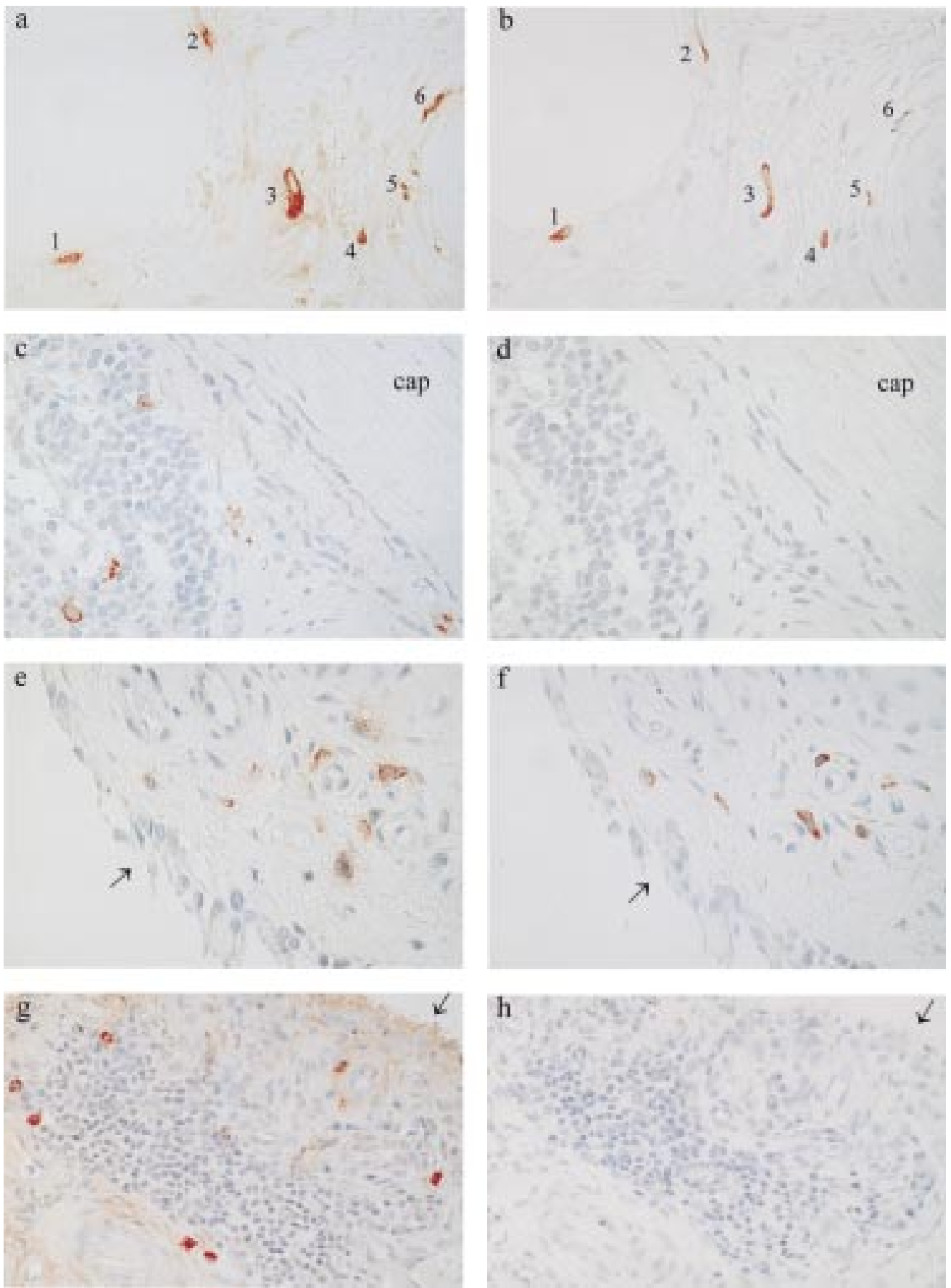

Figure 1 Two $\mu m$ serial sections of skin (a) (b), tonsil (c) (d), and $4 \mu \mathrm{m}$ sections of $R A$ synovium $(e)(f)$ (g) (h) were stained for tryptase (a) (c) (e) (g) and with avidin (b) (d) (f) (h). The arrows indicate the synoviocyte lining layer. In skin where $>99 \%$ of mast cells are $M C_{T C}$, all avidin positive cells (b) (cells 1-6) stained for tryptase (a), confirming that avidin detects $M C_{T C}$ mast cells. In tonsil, no avidin positive cells (d) were found beneath the capsule (cap) or around lymphoid follicles where $M C_{T}$ are known to be present (c), indicating that avidin does not bind to $M C_{T}$ mast cells. These staining results are consistent with the known distribution of $M C_{T C}$ within skin and tonsil and validate avidin as a marker of $M C_{T C}$. Adjacent sections from a patient with $R A(e)(f)$ show $M C_{T C}$ around subsynovial venules in an area with relatively few lymphocytes and a thin synovial lining layer. The tryptase positive mast cells in (e) also stain with avidin ( $f$ ). Adjacent sections from another $R A$ patient $(g)$ (h) show $M C_{T}$ around a collection of lymphocytes, underneath a hyperplastic synovial lining layer. Tryptase positive mast cells $(g)$ are not detected with avidin $(h)$, indicating these cells are $M C_{T}$ Magnification: all at $\times 500$, except $(g)(h)$ at $\times 312$.

cells. $^{7}$ ABC-HRP did not bind to mast cells beneath the epithelium or around lymphoid follicles where $\mathrm{MC}_{\mathrm{T}}$ are found (fig $1 \mathrm{c}$ and $\mathrm{d}$ ). Thus, the staining results confirm that avidin in ABC-HRP binds selectively to $\mathrm{MC}_{\mathrm{TC}}$ and can be used as a quantitative marker for these cells in formalin fixed tissue.

\section{HISTOMORPHOMETRY}

The total mast cell population was determined by staining for tryptase, which is found in both $\mathrm{MC}_{\mathrm{T}}$ and $\mathrm{MC}_{\mathrm{TC}}$ subsets. For all samples, the adjacent section was stained with avidin, which localised to the $\mathrm{MC}_{\mathrm{TC}}$ subset. The density of $\mathrm{MC}_{\mathrm{T}}$ was derived from these two values. 
Table 1 Mean (SD) mast cell density (cells/ $\mathrm{mm}^{2}$ ) in normal synovium, early $R A$, and late $R A$

\begin{tabular}{llll}
\hline & $\neq$ Normal $(n=15)$ & Early $R A(n=22)$ & $\neq$ Late $R A(n=16)$ \\
\hline Total mast cells & $9.4(5.1)^{\star}$ & $40.3(27.5)$ & $60.9(35.9) \dagger$ \\
$\quad$ total $\mathrm{MC}_{\mathrm{T}}$ & $1.6(1.6)^{\star}$ & $29.1(26.8)$ & $23.1(21.2)$ \\
$\quad$ total $\mathrm{MC}_{\mathrm{TC}}$ & $7.8(5.2)$ & $11.2(10.1)$ & $38.5(33.1) \dagger$ \\
Superficial mast cells & $26.6(17.6)^{\star}$ & $60.5(29.6)$ & $59.1(45.2)$ \\
$\quad$ superficial $\mathrm{MC}_{\mathrm{T}}$ & $8.8(8.7)^{\star}$ & $43.9(30.6)$ & $39.3(38.7)$ \\
$\quad$ superficial $\mathrm{MC}_{\mathrm{TC}}$ & $17.9(16.6)$ & $16.7(17.3)$ & $19.9(28.7)$ \\
Deeper mast cells & $6.2(4.6)^{\star}$ & $34.2(29.0)$ & $60.1(36.0) \dagger$ \\
$\quad$ deeper $\mathrm{MC}_{\mathrm{T}}$ & $0.3(0.5)^{\star}$ & $24.0(27.4)$ & $17.1(15.3)$ \\
deeper $\mathrm{MC}_{\mathrm{TC}}$ & $5.9(4.6)^{\star}$ & $10.2(9.4)$ & $43.1(36.2) \dagger$ \\
\hline
\end{tabular}

${ }^{\star} \mathrm{p}<0.05$ for normal synovium compared to early RA. $\dagger \mathrm{p}<0.05$ for late RA compared with early RA. $\ddagger$ Data from reference 4 .

Sections adjacent to the ones stained for mast cells were stained with haematoxylin and eosin. These sections were analysed for synoviocyte hyperplasia, vascularity and perivascular, focal and diffuse infiltration of lymphocytes. Lymphocytic infiltration was confirmed on further sections stained for the pan $\mathrm{T}$ cell marker,
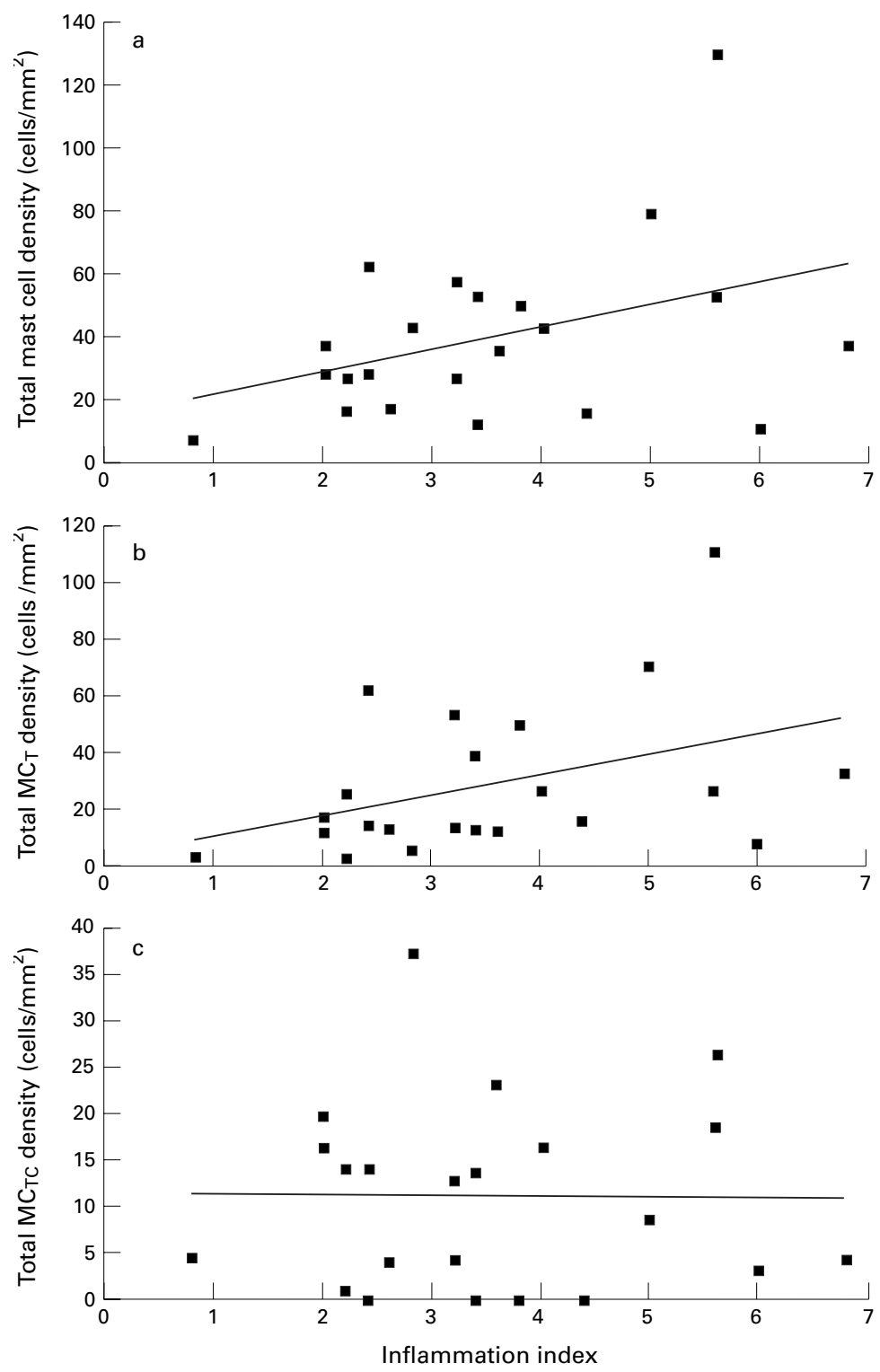

Figure 2 Relation of mast cells to inflammation index. There was a significant correlation between (a) total mast cell density and the inflammation index $(r=0.39, p<0.05)$. When mast cell subsets were examined, this relation was because of the $M C_{T}$ subset, with (b) a significant correlation between $M C_{T}$ density and the inflammation index $(r=0.4, p<0.05)$. (c) No correlation was observed between the inflammation index and the $M C_{T C}$ density.
CD3. These parameters were graded according to the criteria of Rooney et $a l^{19}$ and an inflammation index was derived. The slides remained coded until mast cell densities and histological assessments of synovitis had been performed.

To compensate for variability in inflammation, mast cell density, and other histological parameters that may be present in rheumatoid synovium, a rigorous quantitative histomorphometric system was used, as previously described. ${ }^{4}$ After staining, the synoviocyte lining layer was identified in each specimen and tissue was analysed to a depth of $1 \mathrm{~mm}$. A large total area of synovium was then analysed, with a mean area of synovial tissue examined in the 22 samples of $4 \mathrm{~mm}^{2}$. The total area was subdivided into two; the superficial layer defined tissue within $100 \mu \mathrm{m}$ of the intimal layer, and the deeper layer, which comprised the rest of the section. All mast cells within each area analysed were individually counted using a computer based morphometric system $^{425}$ and an Olympus microscope at $\times 125$ magnification.

\section{STATISTICAL METHODS}

When examining the correlation between mast cell density and clinical or histological indices of disease severity, the one tailed Pearson's $r$ test was used. When the mast cell density was compared with that in late RA, the one tailed Student's $t$ test was used. One tailed tests were used as we expected to find a positive relation between mast cells and clinical and histological evidence of inflammation.

\section{Results}

SYNOVIAL MAST CELL DENSITY AND SUBSET DISTRIBUTION IN EARLY RA

As the RA synovia were collected from patients with early disease and at follow up, this allowed the results to be analysed in two ways. Firstly, the 22 samples of synovia were grouped together, representing the early RA response at various stages of disease activity. The mast cell response in each sample was compared with histological and clinical data. Secondly, as the 22 samples were taken in a longitudinal fashion from six patients, the mast cell responses before treatment were compared with those after treatment induced clinical improvement.

The overall mean synovial mast cell density in the 22 samples was 40.3 cells $/ \mathrm{mm}^{2}$, with regional densities of 60.6 mast cells $/ \mathrm{mm}^{2}$ in the superficial layer and 34.2 mast cells $/ \mathrm{mm}^{2}$ in the deeper layer (table 1). When mast cell subsets were examined, the $\mathrm{MC}_{\mathrm{T}}$ subset predominated, outnumbering $M_{\mathrm{TC}}$ cells by $3: 1$. This ratio was approximately the same in both superficial and deeper layers of the synovium. There was a predominance of $\mathrm{MC}_{\mathrm{T}}$ over $\mathrm{MC}_{\mathrm{TC}}$ in the superficial layer of 17 of 21 specimens (in one specimen no mast cells were seen in the superficial layer). Similarly in the deeper layer, $\mathrm{MC}_{\mathrm{T}}$ predominated in 13 of 22 specimens. $\mathrm{MC}_{\mathrm{T}}$ were seen in all specimens. In four specimens, no $\mathrm{MC}_{\mathrm{TC}}$ were seen, resulting in only $\mathrm{MC}_{\mathrm{T}}$ being present in both superficial and deeper layers of these specimens. Thus, the pattern in 
Table 2 Comparison of mean (SD) values of the clinical index, CRP ( $\mathrm{mg} / \mathrm{l})$, inflammation index, and mast cell density (cells $\left./ \mathrm{mm}^{2}\right)$ at baseline and final biopsy time points $(n=6)$

\begin{tabular}{lll}
\hline & $\begin{array}{l}\text { Baseline biopsy } \\
\text { (untreated) }\end{array}$ & $\begin{array}{l}\text { Final biopsy } \\
\text { (after treatment) }\end{array}$ \\
\hline Clinical index & $6.3(1.5)$ & $0.6(0.4)$ \\
CRP & $60.0(37.0)$ & $2.7(2.2)$ \\
Inflammation index & $5.1(1.5)$ & $2.7(0.6)$ \\
Total mast cell density & $45.9(44.5)$ & $38.5(16.9)$ \\
Superficial mast cell density & $43.5(43.3)$ & $68.9(21.9)$ \\
Deeper mast cell density & $47.8(47.5)$ & $26.9(15.8)$ \\
\hline
\end{tabular}

early RA was expanded numbers of $\mathrm{MC}_{\mathrm{T}}$ cells in both superficial and deeper layers.

These results were compared with those that we have previously reported in RA synovia from patients with longstanding disease (mean duration $=18$ years), and from samples of normal synovium obtained from postmortem examination $^{4}$ (table 1). There were significant differences in the mast cell responses in early versus late RA. Mast cell density was significantly increased in early RA compared with normal synovium, but was less than the response seen in late RA. Whereas the density of both subsets was substantially increased in late disease compared with normal, the increase in mast cells in early RA was nearly exclusively because of an 18-fold expansion of $\mathrm{MC}_{\mathrm{T}}$, with little increase in the $\mathrm{MC}_{\mathrm{TC}}$ subset. The pattern of response in early versus late RA was identical in the superficial synovial layer. However, there were significantly less total mast cells in the deeper layer in early versus late $\mathrm{RA}$, and this was entirely because of a lack of expansion of $\mathrm{MC}_{\mathrm{TC}}$ mast cells in this region. Moreover, whereas the typical pattern noted in late $\mathrm{RA}$ was $\mathrm{MC}_{\mathrm{T}}$ predominating in the superficial layer with $\mathrm{MC}_{\mathrm{TC}}$ prominent in the deeper layer, in early $\mathrm{RA}, \mathrm{MC}_{\mathrm{T}}$ were predominant in

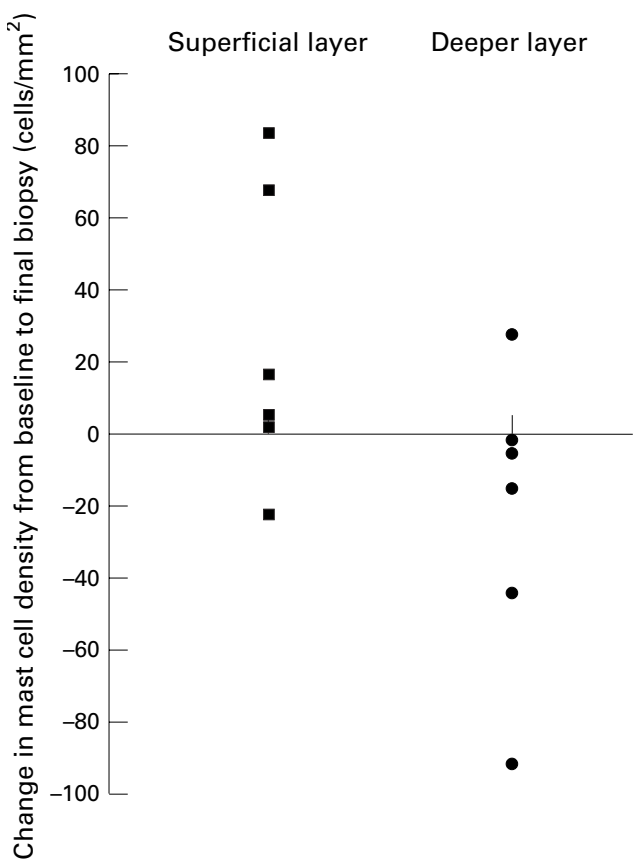

Figure 3 The changes in synovial mast cell density between final and baseline biopsies. Each point represents the changes seen in the superficial or deeper layers of synovia from patients 1 to 6. both regions of synovium. Once again, this was because of a relative lack of expansion of $\mathrm{MC}_{\mathrm{TC}}$ in the deeper layer.

\section{RELATION OF MAST CELLS TO SYNOVITIS AND} CLINICAL PARAMETERS

There was a significant correlation between the total mast cell density throughout the synovium and the inflammation index $(r=0.39, \mathrm{p}$ $<0.05$ ) (fig 2a). When mast cell subsets were examined, it was clear that this relation was because of the $\mathrm{MC}_{\mathrm{T}}$ subset, with a significant correlation between $\mathrm{MC}_{\mathrm{T}}$ density throughout the tissue and the inflammation index $(r=0.4$, $\mathrm{p}<0.05$ ) (fig $2 b$ ). No correlation was observed between the inflammation index and the $\mathrm{MC}_{\mathrm{TC}}$ density (fig 2c). $\mathrm{MC}_{\mathrm{TC}}$ were not found in areas with prominent inflammatory changes (fig $1 \mathrm{e}$ and $\mathrm{f}$ ). However, $\mathrm{MC}_{\mathrm{T}}$ were frequently found close to infiltrating inflammatory cells, lymphocytes, and areas where the synoviocyte lining layer was hyperplastic (fig $1 \mathrm{~g}$ and $\mathrm{h}$ ).

CHANGES IN SYNOVIAL MAST CELL RESPONSES DURING CLINICAL IMPROVEMENT

All patients improved clinically from the beginning to the end of the study period (table $2)$. The mean CRP and clinical index decreased from the baseline to final biopsies (60 to $2.7 \mathrm{mg} / 1$ and 6.3 to 0.6 , respectively, $\mathrm{p}<0.05$ for both). Furthermore, the inflammation index decreased significantly from 5.1 to 2.7 (p $<0.05$ ). At baseline before treatment with disease modifying drugs, the mast cell density was uniform throughout the synovium being equal in both superficial and deeper layers. During clinical improvement, there was no significant change in the total mast cell density. However, there appeared to be a redistribution of mast cells throughout the synovium with an increase in the mean mast cell density in the superficial layer and a decrease in the deeper layer (table 2). This pattern was confirmed when the changes in individual patients were examined. The mast cell density increased in five patients in the superficial layer, and decreased in five patients in the deeper layer (fig 3). There was a trend showing the increase in the superficial layer was largely because of expansion of the $\mathrm{MC}_{\mathrm{T}}$ subset and the decrease in the deeper layer because of reduction in the $\mathrm{MC}_{\mathrm{TC}}$ subset. There was no significant change in the vascularity of the synovial samples during clinical improvement.

The pattern of mast cell response varied at different timepoints in individual patients. For example, in one patient (fig 4a), the total mast cell density remained stable over the study period. However, the $\mathrm{MC}_{\mathrm{T}}$ density decreased while there was a reciprocal increase in $\mathrm{MC}_{\mathrm{TC}}$ density. In this patient, at the baseline, four, and seven month biopsies, there was a predominance of $\mathrm{MC}_{\mathrm{T}}$ over $\mathrm{MC}_{\mathrm{TC}}$, whereas at the 12 month biopsy, the $\mathrm{MC}_{\mathrm{TC}}$ subset was predominant. In another patient (fig $4 \mathrm{~b}$ ), there was a dramatic reduction in total mast cell density after intravenous methylprednisolone, and over subsequent biopsies there was a progressive increase in the $\mathrm{MC}_{\mathrm{T}}$ density. These patients demonstrate the pattern seen in four of 

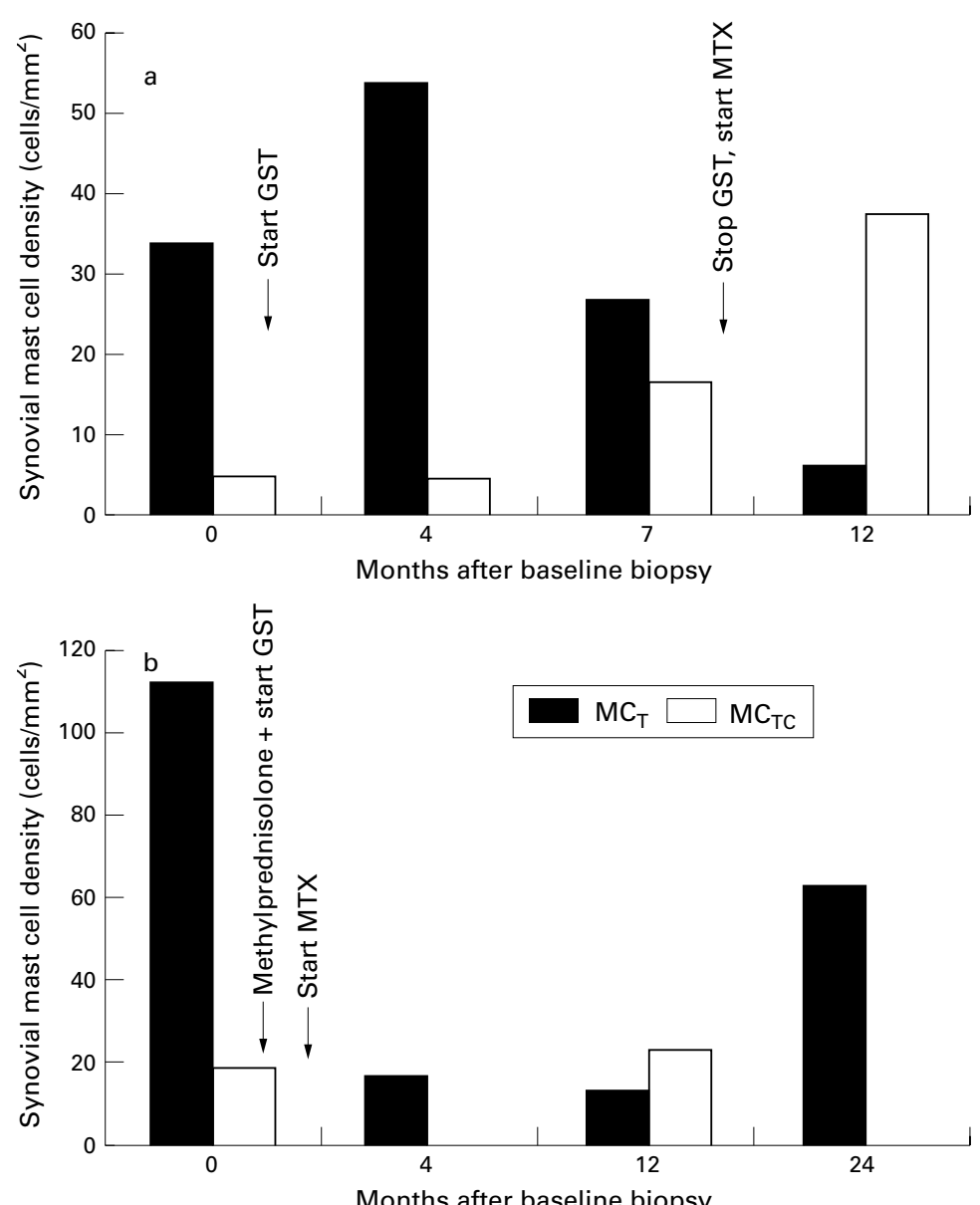

Figure 4 Individual patient mast cell responses at different time points. In patient (a), the total mast cell density remained stable over the study period. However, the $M C_{T}$ density decreased while there was a reciprocal increase in $M C_{T C}$ density. In patient (b), there was a dramatic reduction in total mast cell density after intravenous methylprednisolone, and over subsequent biopsies there was a progressive increase in the $M C_{T}$ density.

six patients, where the predominant mast cell subset that was expanded in individual patients did not appear to be a fixed response, but varied over time. In two patients the $\mathrm{MC}_{\mathrm{T}}$ subset was predominant at all the biopsy time points. In no patient was the $\mathrm{MC}_{\mathrm{TC}}$ subset predominant at all the biopsy time points.

EFFECT OF TREATMENT ON SYNOVIAL MAST CELL DENSITY

The six patients were treated with a variety of drugs; two patients received a single intravenous injection of $1 \mathrm{~g}$ of methylprednisolone at the onset of treatment, four patients were given gold sodium thiomalate (GST), four were given methotrexate (MTX), and one was treated with sulphasalazine (SSZ). The patients were grouped in a variety of ways according to the effect (overall increase or decrease) on the synovial mast cell density throughout the whole synovial tissue, the superficial or deeper layers. Two patients treated with GST and subsequently changed over to MTX and one patient treated with MTX alone had an increase in the total number of synovial mast cells at the end of the follow up period compared with the baseline biopsy. Two patients treated with intravenous methylprednisolone and GST (one of these patients was given combination treatment with MTX), and one patient treated with SSZ had a fall in mast cell density over the study period. The limited number of patients and the lack of a standardised treatment protocol meant that a predictable pattern of the effect of individual drugs on synovial mast cell density did not emerge.

\section{Discussion}

We recently highlighted the increased synovial mast cell density that occurs in RA of relatively long duration, and noted that the $\mathrm{MC}_{\mathrm{TC}}$ subset of mast cells was associated with regions in the synovium of "active" fibrosis. ${ }^{4}$ A correlation between $\mathrm{MC}_{\mathrm{TC}}$ cells and parameters of rapidly progressive disease suggested that this subset was important in the destructive processes or the resulting repair mechanisms that occur in $\mathrm{RA}$, or both. We noted that some synovia had a predominant expansion of the $\mathrm{MC}_{\mathrm{T}}$ subset of mast cells, which were often found associated with infiltrating leucocytes. However, it was unclear whether the predominance of one or other mast cell subset was a fixed response in an individual, or whether this reflected the types of inflammatory processes occurring in the synovium.

This study has considered these questions and in addition, has provided new information concerning the mast cell response in early RA, and the changes that occur during clinical improvement. Firstly, we have shown that similar to late RA, the mast cell density was significantly increased in early RA compared with normal synovium. However, in contrast with late RA, the expansion was mostly restricted to the superficial synovial layer, and was because of a selective increase in the $M_{T}$ subset, the density of which directly correlated with the histological index of inflammation $(r=$ $0.4, \mathrm{p}<0.05$ ) (fig $2 \mathrm{~b}$ ). Secondly, when synovia from the same patients were examined sequentially over time, the mast cell densities changed as did the predominant subset, indicating that RA patients are not committed either to $M_{T}$ or $\mathrm{MC}_{\mathrm{TC}}$ subset predominance throughout the course of their disease. The ability of the predominant mast cell subset to change over time suggests that the mast cell response is influenced by factors such as inflammatory cells and their products in the local microenvironment. Thirdly, during clinical improvement in the activity of RA, there were changes in the regional mast cell densities, with an increase in the superficial layer and decrease in the deeper layer. Taken together, these findings highlight that the mast cell response in RA varies at different time points during the disease, perhaps reflecting the spectrum of inflammatory events that occur at different stages of RA.

There has been no previous study of mast cell responses soon after symptom onset with follow up in the early stages of the disease. We were able to report the changes in synovial mast cell responses within a mean of eight months from symptom onset and followed up the same patients with serial biopsies over a 9-24 month period, during treatment induced clinical improvement. Over the follow up 
period, all patients demonstrated a marked improvement in clinical indices and CRP, reflecting clinical remission of their disease. This was mirrored by a partial improvement in the inflammation indices. However, in no case did the synovium return to normal, indicating that synovitis persists despite clinical resolution. This concords with Soden et $a l^{26}$ who found inflammatory changes in synovia from clinically uninvolved knee joints in patients with early, active RA.

This study complements and extends the results we have previously published in late $\mathrm{RA},{ }^{4}$ illustrating that there are important features that differentiate the mast cell response in early and late stages of the disease. In early $\mathrm{RA}$, the $\mathrm{MC}_{\mathrm{T}}: \mathrm{MC}_{\mathrm{TC}}$ ratio throughout the synovial tissue was approximately $3: 1$, whereas in late RA it was $2: 3$. The key difference was that in early disease, there was a lack of expansion of the $\mathrm{MC}_{\mathrm{TC}}$ subset that was a prominent finding in late RA (table 1). No specimen in the early RA group had areas of cellular dense fibrous connective tissue that was the hallmark of late RA specimens with high $\mathrm{MC}_{\mathrm{TC}}$ densities. Thus, when comparing early with late RA, the $\mathrm{MC}_{\mathrm{T}}$ subset is prominent in early disease and associated with inflammatory cell infiltration, whereas in late disease the $\mathrm{MC}_{\mathrm{TC}}$ subset is associated with areas of cellular, dense fibrous connective tissue, especially seen in synovia from patients who have severe or rapidly progressive disease.

Although the role of mast cells in rheumatoid inflammation has yet to be defined, two possible functions are participation in matrix turnover and interaction with cells of the adaptive immune system. Mast cells may exert a bi-directional effect on matrix turnover. Mast cell tryptase and chymase have been shown to activate the zymogen forms of the matrix metalloproteinases, prostromelysin, and procollagenase respectively. ${ }^{27}$ On the other hand, mast cells may mediate matrix regeneration as they contain a variety of pro-fibrotic cytokines including $\mathrm{bFGF}^{29}$ and IL $4^{10}$ as well as tryptase, which is mitogenic for cultured fibroblasts. ${ }^{30} \mathrm{Of}$ the two human mast cell subsets, $\mathrm{MC}_{\mathrm{TC}}$ cells are more likely to be involved in these processes. This subset contains chymase, which in addition to activating procollagenase, has been reported to release matrix bound $\mathrm{TGF} \beta,{ }^{31}$ a fibrogenic cytokine, and as noted earlier, $\mathrm{MC}_{\mathrm{TC}}$ preferentially contain IL4. ${ }^{10}$ Our previous study of long duration $\mathrm{RA},{ }^{4}$ in which $\mathrm{MC}_{\mathrm{TC}}$ mast cells were predominantly expanded in areas of cellular fibrotic synovium, especially in patients who had severe or rapidly progressive disease, would be consistent with a role for $\mathrm{MC}_{\mathrm{TC}}$ mast cells in matrix turnover.

On the other hand, the $\mathrm{MC}_{\mathrm{T}}$ subset may be more important in inflammatory events and in interactions with lymphocytes. A dependence on T lymphocyte derived factors has long been recognised for the mucosal subset of murine and rat mast cells, ${ }^{32}$ and human $\mathrm{MC}_{\mathrm{T}}$ mast cells are selectively depleted in patients with $\mathrm{T}$ lymphocyte immunodeficiency. ${ }^{13}$ More recent data indicate that mast cells interact with both $\mathrm{B}$ and $\mathrm{T}$ lymphocytes during bacterial and para- sitic infections (reviewed in Mecheri and David $\left.^{33}\right)$. These interactions include $\mathrm{T}$ cell independent stimulation of $\mathrm{B}$ cell $\mathrm{IgE}$ production, ${ }^{34}$ and presentation of immunogenic peptides to $\mathrm{T}$ cells. ${ }^{356}$ The preferential production of cytokines such as IL4, IL5, and IL6 by $\mathrm{MC}_{\mathrm{T}}$ cells ${ }^{10}$ has been postulated to favour $T_{\text {HELPER }}$ cell differentiation towards a type 2 response. ${ }^{37}$ This bilateral relation between mast cells and lymphocytes may underlie the association of $\mathrm{MC}_{\mathrm{T}}$ cells with inflammatory cells, in particular lymphocytes that we observed.

An interesting, but unexpected finding in this study was that during clinical resolution and histological improvement, although the overall mast cell densities did not change significantly, there were consistent changes in the distribution of mast cells. The mean density of mast cells was virtually the same in both superficial and deep synovial layers at baseline when the disease was highly active (43.5 and 47.8 cells $/ \mathrm{mm}^{2}$ respectively; $\mathrm{n}=6$ ) (table 2). However, the mean mast cell density expanded in the superficial layer (from 43.5 to 68.9 cells/ $\mathrm{mm}^{2}$ ) and decreased in the deeper layer (from 47.8 to 26.9 cells $/ \mathrm{mm}^{2}$ ) at the final biopsy when all patients had improved clinically. Although these results are derived from only six paired biopsies, limiting their interpretation, the trends were consistent (fig 3). Four patients showed an increase in the mast cell density superficially combined with a reciprocal decrease in the deep synovium. One patient showed a decrease in both regions, but the decrease in the deeper layer was fourfold greater than that superficially. The final patient showed an increase in both regions but the increase superficially was nearly three times that in the deeper synovium. Thus, in every case, the net effect during clinical improvement was a lessening of the mast cell response in the deep synovium, relative to the response in the superficial synovial layer.

It is possible that clinical treatment in early RA changed the mast cell response predominantly in the deeper layer, preventing expansion of $\mathrm{MC}_{\mathrm{TC}}$, which we previously found to be associated with progressive disease in late RA. Such a "superficialisation" of the synovial mast cell response may reflect an intermediate stage between mast cell expansion and resolution. Conceivably, mast cell expansion in RA might begin in the superficial synovium after recruitment of mast cell precursors via the subsynovial blood vessels. These mast cell committed progenitors possibly already possess the $\mathrm{MC}_{\mathrm{T}}$ phenotype, ${ }^{38} 39$ or will early in their tissue maturation process. As inflammation becomes chronic, and associated with tissue destruction, mast cells may spread into the deeper synovial regions, perhaps differentiating into $\mathrm{MC}_{\mathrm{TC}}$ cells. With resolution, $\mathrm{MC}_{\mathrm{TC}}$ may revert back to $\mathrm{MC}_{\mathrm{T}}$, and accumulate superficially before gradually exiting from the synovium. The mechanisms underlying mast cell recruitment and differentiation within human tissues are highly controversial, but there is some evidence for such a pathway, ${ }^{40}$ and considerable evidence for this scenario in the murine system. ${ }^{41}{ }^{42}$ In 
any event, the changes observed in the distribution of mast cell subsets during clinical improvement of RA, illustrate that further studies of the mast cell response in this disease are likely to provide additional information, not only about the role of mast cells in RA, but also about the biology of the mast cell itself.

This work was supported by grants from the Arthritis Foundation of Australia and the National Health and Medical Research Council of Australia.

1 McNeil HP. The mast cell and inflammation. Aust N Z J Med 1996;26:216-25.

2 Tetlow LC, Woolley DE. Distribution, activation and tryptase/chymase phenotype of mast cells in the rheumatryptase/chymase phenotype of mast cells in
toid lesion. Ann Rheum Dis 1995;54:549-55.

3 Tetlow LC, Woolley DE. Mast cells, cytokines, and metalloproteinases at the rheumatoid lesion: dual immunolocalisaproteinases at the rheumatoid lesion: dual immun
tion studies. Ann Rheum Dis 1995;54:896-903.

4 Gotis-Graham I, McNeil HP. Mast cell responses in rheumatoid synovium - association of the $\mathrm{MC}_{\mathrm{TC}}$ subset with matrix turnover and clinical progression. Arthritis Rheum 1997;40:479-89.

5 Tetlow LC, Harper N, Dunningham T, Morris MA, Bertfield H, Wooley DE. Effects of induced mast cell activation on prostaglandin $\mathrm{E}$ and metalloproteinase production by rheumatoid synovial tissue in vitro. Ann Rheum Dis 1998; $57: 25-32$

6 Irani AA, Schechter NM, Craig SS, DeBlois G, Schwartz LB. Two types of human mast cells that have distinct neutral protease compositions. Proc Natl Acad Sci USA 1986; 83:4464-8.

7 Irani AM, Bradford TR, Kepley CL, Schechter NM, Schwartz $\mathrm{LB}$. Detection of $\mathrm{MC}_{\mathrm{T}}$ and $\mathrm{MC}_{\mathrm{TC}}$ types of human
mast cells by immunohistochemistry using new monomast cells by immunohistochemistry using new mono-
clonal anti-tryptase and anti-chymase antibodies. J Histoclonal anti-tryptase and anti-chyma

8 Irani A-MA, Goldstein SM, Wintroub BU, Bradford T, Schwartz LB. Human mast cell carboxypeptidase. Selective localization to $\mathrm{MC}_{\mathrm{TC}}$ cells. J Immunol 1991;147:247-53.

9 Schechter NM, Irani A-MA, Sprows JL, Abernethy J, Wintroub B, Schwartz LB. Identification of a cathepsin G-like proteinase in the $\mathrm{MC}_{\mathrm{TC}}$ type of mast cell. J Immunol 1990; 145:2652-61.

10 Bradding P, Okayama Y, Howarth PH, Church MK, Holgate ST. Heterogeneity of human mast cells based on cytokine content. J Immunol 1995;155:297-307.

11 Patella V, DeCrescenzo G, Ciccarelli A, Marino I, Adt M, Marone G. Human heart mast cells: a definitive case of mast cell heterogeneity. Int Arch Allergy Immunol 1995;106:386-93.

12 DePaulis A, Marino I, Ciccarelli A, DeCrescenzo G, Concardi M, Verga L, et al. Human synovial mast cells I. Ultrastructural in situ and in vitro immunologic characterization. Arthritis Rheum 1996;39:1222-33.

13 Irani AM, Craig SS, DeBlois G, Elson CO, Schechter NM, Schwartz LB. Deficiency of the tryptase-positive, chymasenegative mast cell type in gastrointestinal mucosa of patients with defective T lymphocyte function. J Immunol 1987; 138:4381-6.

14 Algermissen B, Bauer F, Schadendorf D, Kropp JD, Czarnetzki BM. Analysis of mast cell subpopulations $\left(\mathrm{MC}_{\mathrm{T}}, \mathrm{MC}_{\mathrm{TC}}\right)$ in cutaneous inflammation using nove enzyme-histochemical staining techniques. Exp Dermato 1994;3:290-7.

15 Irani AM, Gruber BL, Kaufman LD, Kahaleh MB, Schwartz LB. Mast cell changes in scleroderma. Presence of $\mathrm{MC}_{\mathrm{T}}$ cells in the skin and evidence of mast cell activation. Arthritis Rheum 1992;35:933-9.

16 Arnett FC, Edworthy SM, Bloch DA, McShane DJ, Fries $\mathrm{JF}$, Cooper NS, et al. The American Rheumatism Associa-
tion 1987 revised criteria for the classification of rheumatoid arthritis. Arthritis Rheum 1988;31:315-24.

17 Smith MD, Chandran G, Youssef PP, Darby T, Ahern MJ Day case arthroscopy under regional anaesthesia, performed by rheumatologists. Aust N Z J Med 1996;26: $108-9$.

18 Youssef PP, Triantafillou S, Parker A, Coleman M, RobertsThomson PJ, Ahern M, et al. Effects of pulse methylprednisolone on cell adhesion molecules in the synovia membrane in rheumatoid arthritis. Arthritis Rheum 1996 39:1970-9.

19 Rooney M, Condell D, Quinlan W, Daly L, Whelan A, synovitis in rheumatoid arthritis. Arthritis Rheum 1988;31: $956-63$

20 Youssef PP, Triantafillou S, Parker A, Coleman M, RobertsThomson PJ, Ahern MJ, et al. Variability in cytokine and cell adhesion molecule staining in arthroscopic synovial biopsies: quantitation using color video image analysis. J Rheumatol 1997;24:2291-8.

21 Walls AF, Jones DB, Williams JH, Church MK, Holgate ST. Immunohistochemical identification of mast cells in formaldehyde-fixed tissue using monoclonal antibodies specific for tryptase. J Pathol 1990;162:119-26.

22 Weidner N, Austen KF. Heterogeneity of mast cells at multiple body sites. Fluorescent determination of avidin binding and immunofluorescent determination of chymase, tryptase, and carboxypeptidase content. Pathol Res Pract 1993;189:156-62.

23 Bergstresser PR, Tigelaar RE, Tharp MD. Conjugated avidin identifies cutaneous rodent and human mast cells. J Invest Dermatol 1984;83:214-18.

24 Tharp MD, Seelig LL, Jr., Tigelaar RE, Bergstresser PR. Conjugated avidin binds to mast cell granules. J Histochem Cytochem 1985;33:27-32

25 Halasz P, Huang XF, Turk I. Enhanced magellan computer program for the three-dimensional reconstruction of labelled neuronal cell populations. [Abstract]. Proceedings of the Australian Neuroscience Society 1992;3:143.

26 Soden M, Rooney M, Cullen A, Whelan A, Feighery C, Bresnihan B. Immunohistological features in the synovium obtained from clinically uninvolved knee joints of patients with rheumatoid arthritis. Br J Rheumatol 1989;28:287-

Gruber BL, Schwartz LB, Ramamurthy NS, Irani AM, Marchese MJ. Activation of latent rheumatoid synovial collagenase by human mast cell tryptase. J Immunol $1988 ; 140: 3936-42$.

28 Saarinen J, Kalkkinen N, Welgus HG, Kovanen PT. Activation of human interstitial procollagenase through direct cleavage of the Leu83-Thr84 bond by mast cell chymase. J Biol Chem 1994;269:18134-40.

29 Qu Z, Liebler JM, Powers MR, Galey T, Ahmadi P, Huang $\mathrm{XN}$, et al. Mast cells are a major source of basic fibroblast growth factor in chronic inflammation and cutaneous hemangioma. Am J Pathol 1995;147:564-73.

30 Ruoss SJ, Hartmann T, Caughey GH. Mast cell tryptase is a mitogen for cultured fibroblasts. J Clin Invest 1991;88: mitoge.

31 Taipale J, Lohi J, Saarinen J, Kovanen PT, Keski-Oja J. Human mast cell chymase and leukocyte elastase release latent transforming growth factor-beta 1 from the extracellular matrix of cultured human epithelial and endothelial cells. J Biol Chem 1995;270:4689-96.

32 Mayrhofer G, Bazin H. Nature of the thymus dependency of mucosal mast cells III. Mucosal mast cells in nude mice and nude rats, in B rats and in a child with Di George syndrome. Int Arch Allergy Applied Immunol 1981;64:32031.

33 Mecheri S, David B. Unravelling the mast cell dilemma: culprit or victim of its generosity? Immunol Today culprit or victim.

34 Gauchat JF, Henchoz S, Mazzei G, Aubry JP, Brunner T, Blasey H, et al. Induction of human IgE synthesis in B cells
by mast cells and basophils. Nature 1993;365:340-3.

35 Frandji P, Oskeritzian C, Cacaraci F, Lapeyre J, Peronet R, David $\mathrm{B}$, et al. Antigen-dependent stimulation by bone marrow-derived mast cells of MHC class II-restricted T cell hybridoma. J Immunol 1993;151:6318-28.

36 Fox CC, Jewell SD, Whitacre CC. Rat peritoneal mast cells present antigen to a PPD-specific T cell line. Cell Immunol 1994;158:253-8.

37 Romagnani S. Induction of $\mathrm{TH} 1$ and $\mathrm{TH} 2$ responses: a key role for the 'natural' immune response. Immunol Today 1992;13:379-80.

38 Baghestanian M, Bankl H, Sillaber C, Beil WJ, Radaszkiewicz T, Fureder W, et al. A case of malignant mastocytosis with circulating mast cell precursors: biologic and phenotypic characterization of the malignant clone. Leukemia 1996;10:159-66.

39 Castells MC, Friend DS, Bunnell CA, Hu X, Kraus M, Osteen RT, et al. The presence of membrane-bound stem cell factor on highly immature nonmetachromatic mast cells in the peripheral blood of a patient with aggressive systemic mastocytosis. J Allergy Clin Immunol 1996;98: 831-40.

40 Toru H, Eguchi M, Matsumoto R, Yanagida M, Yata J, Nakahata T. Interleukin-4 promotes the development of tryptase and chymase double-positive human mast cells accompanied by cell maturation. Blood 1998;91:187-95.

$41 \mathrm{McNeil} \mathrm{HP}$, Austen KF. Cytokine regulation of mouse mast cell-specific protease genes. In: Samuelsson B, Dahlen S-E, Fritsch J, Hedqvist P, eds. Advances in prostaglandin, thromboxane and leukotriene research. Vol 22. New York: Raven Press, 1994:71-81.

42 Friend DS, Ghildyal N, Austen KF, Gurish MF, Matsumoto R, Stevens RL. Mast cells that reside at different locations in the jejunum of mice infected with Trichinella spiralis exhibit sequential changes in their granule ultrastructure and chymase phenotype. J Cell Biol 1996;135: 279-90. 